\title{
Popular music, history and geography of our society: a pedagogical approach for students
}

\section{La música popular, historia y geografía de nuestra sociedad: un enfoque pedagógico para los estudiantes}

\author{
MENDOZA-ZAZUETA, Juan Enrique†๋* \& ÓSCAR-ÁVILA José Melchor \\ Universidad Autónoma de Sinaloa, Facultad de Filosofía y Letras, Cuerpo Humanismo e Identidad Cultural \\ Universidad Autónoma de Sinaloa, Unidad Académica de Artes, Escuela de Música
}

ID $1^{\text {st }}$ Author: Juan Enrique, Mendoza-Zazueta / ORC ID: 0000-0002-6597-2754, arXiv Author ID: jemendoza, SNI CONACYT ID: 271063

ID $1^{\text {st }}$ Coauthor: José Melchor, Óscar-Ávila / ORC ID: 0000-0003-0586-4812

DOI: $10.35429 / J T E R .2020 .17 .6 .1 .9$

Received February 10, 2020; Accepted April 01, 2020

\begin{abstract}
The present work seeks to determine popular music as an object of study before the cultural interconnections given by globalization and, at the same time, presenting the musical field as a pedagogical tool for education. Through a project by researchers at the Autonomous University of Sinaloa, a pedagogical methodology that provides the student with tools necessary for an understanding from the regional to the global of the object of study is weighted, this being the musical field or any other object of which music can serve as a tool for the acquisition and understanding of knowledge. It also proposes the construction and protection of documents that help shape our history, understanding that intellectual operations encompass both languages and multiple discourses as well as artistic expressions in general.
\end{abstract}

Popular music, musical pedagogy, regional music, teaching

\begin{abstract}
Resumen
El presente trabajo busca determinar a la música popular como objeto de estudio ante las interconexiones culturales dadas por la globalización $\mathrm{y}$, al mismo tiempo, presentando al campo musical como una herramienta pedagógica para la educación. A través de un proyecto por parte de los investigadores de la Universidad Autónoma de Sinaloa, se pondera una metodología pedagógica que proporcione al estudiante herramientas necesarias para una comprensión desde lo regional a lo global del objeto de estudio, siendo este el campo musical o cualquier otro objeto del cual la música pueda servir como herramienta para la adquisición y comprensión del conocimiento. Asimismo, se propone la construcción y protección de documentos que ayudan a dar forma a nuestra historia, entendiendo que las operaciones intelectuales abarcan tanto los lenguajes y los múltiples discursos como las expresiones artísticas en general.
\end{abstract}

Música popular, pedagogía musical, música regional, didáctic

Citation: MENDOZA-ZAZUETA, Juan Enrique \& ÓSCAR-ÁVILA José Melchor. Popular music, history and geography of our society: a pedagogical approach for students. Journal of Teaching and Educational Research. 2020. 6-17: 1-9.

\footnotetext{
* Correspondence to the Author (Email: juanmendoza@uas.edu.mx)

$\dagger$ Researcher contributing as first author.
} 


\section{Introduction}

Art education in students at different school levels is, today, a part that is becoming more substantive in school life, is to think in an intellectual, social, professional and spiritual aspect, in a harmonious, balanced relationship that favors the individual a possibility to approach and establish a new relationship with his society, community, reflective or inclusive.

Thus, our country is in transitions of the political, economic, social and cultural orders. But all these changes have permeated social consciousness, in the cultural sphere, that is, in what is known as popular culture, what Mikhail Bakhtin analyzed, in his most influential work written in 1941, Popular culture in the Middle Ages and in the Renaissance: the context of François Rabelais, in this text we can see that carnival and bufo world, as opposed to a normative world, with a rigidity of preestablished artistic patterns and styles, thus the other discourse is broad and polyphonic, born of artistic and folkloric manifestations that come directly from a system of values and traditions of the people. Following on these lines, the term popular music, first used in 1573, is conceptualized, encompassing a variety of styles that are associated with different groups and social classes (Pérez-Aldeguer, 2014). Seen in this way, popular music fosters intercultural competence, as it is a transversal axis, which in the educational field fostered a new relationship of its society based on knowledge, from this point of view, in relation to other societies.

While the importance of education, art, and music in particular has been seen for years as a substantive part, at least that is what we can observe World Conference on Education for All held in Thailand (UNESCO, 1990), the socalled inclusive education was generated, giving popular music a degree of importance to achieve that proposal, contextualizing it since then, but its growth in relation to other areas such as science, technology, communication, has been much less, although World Conference on Higher Education, since 1998 (UNESCO) encouraged the search for new ways of distributing knowledge, in an effort to encourage countries around the world not to fall behind, which could carry a high cost, a year later, Talks about inclusive education, progress on these issues has been less.
Various studies such as that of Anne Bamford, (2006), The Wow Factor: Global research compendium on the impact of the arts in education, support the qualities that on social inclusion foster music, hinting at the different types to which it refers inclusion is to say religious, racial or social class.

Other studies talk about the musical experience and the way in which it generates a synergy between teachers, students and parents, in this way it ceases to be an object to transform itself into an experience that facilitates social inclusion (Frith, 1987). With which the strength of educating through and from the musical is accentuated, accentuating from listening, singing, interpretation, creation, and corporal expression, to name a few.

It will be during the time of Vasconcelos at the head of the Ministry of Public Education, 1921-1924, where his project is based on thirteen founding axes, which were, education, fine arts and books as trainers in the field educational of the individual, it was in that period in which an attempt was made to give a training made up of the member who will converge the student from what is expressed in science and art, outside of that period our country found in a constant justification, "In In the cultural field, some ideological elements of the state apparatus have acted vastly, elements that are thus perfected, stabilized or deteriorated in the broad period 1917-1975, continue to lead substantially to the same thing: progress as justification and ultimate meaning of Mexico "(Monsivais, 2000). 
Thus, in the field of professional arts, ruptures, rejections, justifications have been generated, establishing relationships that sometimes focus on the sense of identity and exacerbated nationalism, as in the case of the 1950 s, or an innovation and openness that is more well it remains in a whirlpool that could not be capitalized and only remained in an idea, so we reached the '80s a new mentality, all because of a new relationship with the knowledge of the individual, but that was conceived in a cultural relativism that also failed consolidating this integral idea, the neoliberal policies of the 90s, only generate the cultural aria to move away, although on the other hand the folkloric has been exacerbated, but seen only as a nationalist, identity, impressionist ebb, and not as an emanation of the popular, but as a stratification of an exportable use of a past photograph of our society, thus during that decade and the following one the debate was $m$ It mixes with globalization and appears "a universal consumer capable of deciphering advertising messages and even demanding contractual satisfactions beyond national jurisdictions" (Bolán, 2002). With which the positions that have been marked for years are accentuated, one that looked towards cultural localisms, regionalisms, in search of acceptance and legitimation, and another marked by authoritarianism and paternalism.

Music education is a pending subject, in a study carried out by Ortiz Molina (2011), it opens a series of questions in which we observe a distinction between the general musician and the music specialist, the latter seen as those who had an education Classical musical, that is academic, which causes a gap to be generated between one and other teachers, emphasizing what is valued academically with greater prestige, leaving aside the possibility of giving access to other forms of popular music understand and understand other musical practices, which are anchored in traditions, beliefs and values in relation to time and place, thus having a means of social and cultural involvement, opening a manifestation within the framework of a human context in which it arises already exists (Tejada, 20104), thus achieving an approach from another position to the object, thus uniting the environment of my music with the music of other cultures, and observing the intercommunication that in a temporary evolution has been taking place, with which the individual expands at the same time as concrete a global panorama uncertain in its regionality.

ISSN-2444-4952

ECORFAN $^{\circledR}$ Todos los derechos reservados
Expanding this spectrum leads us to observe horizontally and vertically the forms, uses and customs that are used in the research, study, pedagogy and teaching of popular music in our country, as well as the value that is given to it in different verticalities of is that make up the society in which the individual develops, we think like Hernández bravo (2011) that they are necessary to develop a series of "cognitive, affective and practical skills necessary to function ... in an intercultural environment" (54 ). With which, it contributes to an understanding from the execution of other practices and forms. Closing gaps from a specialization, and understanding the popular not in derogatory terms, but as a substantive part and a product of expression of our culture, which opens up various techniques and methods to approach and know that universe. Emphasizing the deepening that students acquire in the knowledge of artistic languages and practice it regularly, this in order to integrate attitude skills that involve their thinking (SEP, 2006). The training involves an interweaving of two, leaving aside an empirical skill learned, to generate a series of elements that can lead step by step in a degree from less to greater complexity and deepening of knowledge about the object being studied, make use of of new technologies, contextualize the need and use of these elements in the current educational environment, as mentioned by Díaz (2005) in his study Musical education at school and the European Higher Education Area, which allows us immediate access, unique in relation to other historical moments, of the produced, of the productions and of the information that on the popular in relation to music is developed in the world. In the same way, in Espigares' doctoral thesis (2009): Music education with ICT for secondary school: evaluation of an educationalmusical knowledge management model, (the Bourbon model), states that: The music education model With ICT that it poses as work, it produces an impact on the emotional aspect of the subjects, as well as on their musical skills and competences. In the Bourbon model, it benefits from the possibilities and advantages offered by music science in general, and music education in particular, as referred to in the theoretical section of this research, values, learning and skills are developed musicals in the students, which enhance respect and collective enrichment in their human relationships, something essential in this educational stage, to contribute to the development of their capacities and comprehensive training. 
In addition to what has already been commented in works such as that of Galera (2010) where he alludes to the importance of computer technology in relation to cognition, assistance, for the understanding of the soundsymbol in the musical field, which now intermediate stages, adds to the above the work of Montesinos (2010) The Specialist Teacher: Initial musical training and Praxis of School Musical Education, comments that the relevance of his study consists in knowing its impact on the effectiveness of the educational act in some side effects to the development of the curriculum. He makes special emphasis on the context, where it is carried out, the educational process and what are the real infrastructures for teaching the subject, as well as his assessments of the type of music education that is taught in educational centers. The question arises, whether from music teaching, different practices were generated, the factors that influence the teaching-learning process. It also seeks to explain the impact of music education, and its teachers, and whether they are sufficiently valued by educational institutions, as well as knowing what degree of satisfaction the specialist teacher achieves when developing his teaching practice.

The intention of this project Popular music, history and geography our society: a pedagogical approach for students, is to analyze the positions on popular music at the regional level, throwing lines at the global level, to find the cultural interconnections that have nurtured in the musical field ponder a pedagogical methodology that in an organized way can provide the student with the necessary tools to have a global and total understanding of the object being studied, as well as build and protect documents that help shape our history, understanding that intellectual operations encompass both languages and multiple discourses such as artistic expressions as a whole, the techniques and practices that comprise it.

\section{Problem statement and justification}

Our university, the Autonomous University of Sinaloa, is aware of the changes that are coming and as a precept or fundamental axis is at the same time as the educational and the cultural, observes that this is an identity trait and that it has a value in the regional and therefore an impact towards the national and universal, proof of this is the solid presence that our so-called regional music has in the world, to which must be added the achievements that the academy has had, or that other musical works have had, music is an instrument of the state, of a nation, it is an indelible photograph that goes beyond its state to form an identity. Hence, our interest in specialization, our interest in reflecting on this object that, having it so close at hand, seems to be known, but it is an intention of the academy, it is its duty to study it, think about it and respond to it. the problems and criticism that it brings, music is seen as an accessory in some educational programs, and not as what can contribute to the educational field.

It is the obligation of the universities, as one of the privileged spaces for the creation of knowledge, to participate proactively effectively in the reflection of these new educational paradigms. Our university has generated lines that help strengthen and consolidate this approach.

The didactic aspect of art, which allows organizing and interpreting the various positions that underlie it, observing "the different plots of human knowledge, in what refers to the artistic field, quantifies the meanings, reasons and intentions of the subject who performs the action, does not clarify much when it comes to understanding the changes caused in the producer. This action must be interpreted and understood, and based on that knowledge, propose new didactic learning situations, if desired "Mollá Giner (1994), that is, integrate and train the student with a capacity for analysis based on objects that are presented so that he can discern and find connection points that lead him to consolidate knowledge based on a particular expression. 
But the same that can be extra populated in a transversal way to other school disciplines, and then stop being an accessory to become an educational tool that can favor abstract and theoretical processes, "music contains skills that are present in different subjects and therefore, if we are aware of this, we can facilitate the access of students to globalized content (Reyes, 2011).

Experiences from other countries can be extrapolated to our society, with its exceptions in economic lag, Cuba has managed to consolidate an educational development above many Latin American countries, in turn consolidating the union of the so-called basic subjects and those of an artistic nature, that is, a public policy focused on a comprehensive, inclusive, global education. It is our intention to think about these pedagogical models, give an answer, what are the market needs they are looking for and their internal potential (Moreno, 2010). Do not succumb to the pressures of globalization, rather take strength from them to generate a new proposal that unifies the various positions in the political, economic, social, and so on. Educational policies have to become the target of impacts from abroad, the establishment of a socio-institutional educational framework, which seeks to adapt and contribute to the formation of a new techno-productive paradigm, managed through a neoliberal educational vision, granting Thus, financial support to promote pedagogical and academic models, with a business cut-off called by competencies, for the different levels of the national educational system.

Continuing with Moreno (2010) the IES, in their educational policies led to the socioinstitutional framework, to a triple convergence:

- Training in professional, investigative and managerial competences, supported epistemologically, in the constructivist methodology.

- The notion of training for the knowledge society, knowledge economy and human capital, today converted into digital capital.
- The management of organizational change, and the academic legitimization of HEIs, to adapt them to the new techno-productive model, which began as a structural adjustment in the eighties, was reinforced in the nineties and aims to overwhelm all the academic areas and levels of the system educational towards 2010-2020, by increasing and reinforcing its educational policy instruments such as; hierarchical organization, linking teaching with research and production systems of goods and services and diversification of financial sources, adopt the so-called third modernity which seeks excellence, effectiveness, efficiency, productivity, belonging, competitiveness, evaluation, performance, accreditation, planning, change management, use of new information and communication technologies, global learning networks, among others.

One of the problems we face is the statism in which the academy is in the field of music, it is necessary to propose a new order that addresses the various knowledge that compose it, that is, giving rise to the indigenous, peasant, technical, urban, to name a few. Within a dialogical perspective that promotes interculturality, not as a politically correct assessment of difference, but as a real space for exchange and intertextuality, which does not hide tensions and differences, but rather manages to make them explicit, to make they a fertile place. But also, to leave the gray and uncertain areas still, where cultures simply cannot be found (Samper, 2011).

It is necessary to implement policies that allow the dissemination and standardization of educational models according to the new socioeconomy, which are also involved in the globalization processes in which the students are immersed, it is impossible, to be oblivious to it, a look must be achieved inclusive among the organizations involved.

In our state, music education has different ups and downs, there is no institutional policy in accordance with the new proposals mentioned above, policies that touch on the subject of education at different levels, science, sport and art education, not seeing this last as an accessory but as a substantive and formative integral part of the individual. 
It is counted whether, in the governmental sphere with projects of symphony orchestras, choirs and youth choirs in our state, all this supported by the now Secretary of Culture, before the National Council for Culture and the Arts (CONACULTA), managed to implement the projects of orchestras symphonies, and children's and youth choirs in the state, another effort is also the Artistic Initiation Centers of the Ministry of Public Education, there are also three Bachelor's degrees in Music in our state, these with different accentuations and focused mainly on the practice of certain styles and genres, there is a long way to go it is necessary to integrate research into these centers, it is necessary to think about the how, in relation to music in our area, in our region, that manifestation that emanates from our people and that generates particularities harmonicas, drawing on a past and a present that interact in a live way in the phenomenon, but that has not been Reflected in its entirety in a systematic way and more, made available to our educated as an intangible part of their information society's understanding of a construct of thought. Thinking about pedagogy and music as a tool, as a substantive part in the development of the student, permeates our society, as a reflection of the interrelationships established by the different cultures that have and inhabit our region, the human vocation is privileged over the artistic one, consider it a methodological tool at the service of learning. Include performing art as for its analysis and study, strengthening the writing, logical reasoning and identity skills. In other words, from a critical liberal and social progressive trend (García-Huidobro, 1996).

\section{Hypothesis}

There is no pedagogical system, a didactic guide, an investigation that on the aspect of popular music can generate the interrelationships of the regional and the global, which has led the programs to focus mainly on practice, but it is deprived of the interrelationships that can nurture it, we think that it is through the analysis and knowledge of these relationships that the student is able to acquire and develop their inductive, deductive tools and a criterion on the object. It can also be a participant in the constitution of and its cultures, from the observation through the object of other manifestations in other cultures, with which it can come to establish a criterion on themes, region, globalization, violence and identity.

ISSN-2444-4952

ECORFAN $^{\circledR}$ Todos los derechos reservados

\section{Objective}

Our project "Popular music, history and geography our society: a pedagogical approach for students" proposes us to analyze and explain the various positions on popular music that exist, joining this to the concept of globalization, based on a methodology that goes from the quantitative in terms of the specificity of influences, areas, populations, generations, styles, and all this in a qualitative reflection that helps us to build a thought on the various realities in a temporary evolution. That is, finding the cultural interconnections that have nurtured in the musical field ponder a pedagogical methodology that in an organized way can provide the student with the necessary tools to have a global and total understanding of the object being studied, as well as build and safeguard documents that help shape our history, understanding that intellectual operations encompass both languages and multiple discourses and artistic expressions as a whole, the techniques and practices that comprise it.

\section{Methodology}

It is in our interest in this research to approach education reality from very different perspectives, in addition, to be able to use among many research models and choose different techniques, depending on the approach through which it is intended to make an interpretation of social and educational reality, therefore, it is to be expected that different answers will emerge to the questions asked. The authors who in recent years have contributed, with numerous publications of great influence in the community of social and educational researchers, tending to spread a vision of approaches to social research, based on the Kuhnian concept, of paradigm are: Guba, Denzin and Lincoln. In Mexico, concern for paradigms was strongly introduced in official educational discourses and research in the 1980s. The representative work of that time can be named the one coordinated by Dendaluce (1988). Methodological aspects of educational research, and specifically the contribution of the Spanish researcher De Miguel (1988), paradigms of Spanish educational research.

The field of educational research has been identifying a series of research paradigms, characterized by the responses that its defenders offer to three basic questions, which are related to the object of knowledge or the reality that one wishes to study.

MENDOZA-ZAZUETA, Juan Enrique \& ÓSCAR-ÁVILA José Melchor. Popular music, history and geography of our society: a pedagogical approach for students. Journal of Teaching and Educational Research. 2020 
These questions can be linked to the following dimensions according to (Lincoln, 1990): The Ontological Dimension, The Epistemological Dimension and the Methodological Dimension.

The dimensions will help us to generate a complete panorama, our methodological approach will be mixed, quantitative and qualitative, as mentioned by Hernández (2014), throughout the history of science, various currents of thought have emerged (such as empiricism, dialectical materialism, positivism, phenomenology, structuralism) and various interpretive frameworks such as realism and constructivism, which have opened different routes in the search for knowledge. Both approaches employ careful, methodical, and empirical processes in their effort to generate knowledge, so the previous definition of the research applies to both equally. A mixed approach helps us with the set of systematic, empirical and critical research processes, and involves the collection and analysis of quantitative and qualitative data, as well as their integration and joint discussion, to make inferences as a result of all the information collected, ( meta inferences), and achieve a better understanding of the phenomenon under study (Hernández and Mendoza, 2008).

The mixed approach can be said to use evidence from numerical, verbal, textual, symbolic, and other data to understand the phenomenon of science. Chen (2006) defines them as; The systematic integration of the quantitative and qualitative methods in a single study in order to obtain a more complete picture of the phenomenon, and points out that these can be combined in such a way that the qualitative and quantitative approaches retain their original structures and procedures, ( pure form of mixed methods); or that these methods can be adapted, altered or synthesized to carry out the research and deal with the costs of the study, (modified form of the mixed methods).

For Hernández (2014) the mixed investigation process contains:

\section{Fundamental definitions:}

\section{- Rationalization of the mixed design.}

- Decisions on: a) which instruments will be used to collect the quantitative data and which, for the qualitative data.

ISSN-2444-4952

ECORFAN ${ }^{\circledR}$ Todos los derechos reservados
- b) the priorities of quantitative and qualitative data and analysis.

- c) the way in which different types of data are going to be transformed, associated and / or combined.

- e) method of analysis in each process and stage.

- Decision on how to present the results inherent to each approach and the joint findings.

- The investigation moves dynamically both in the facts and in the interpretation, in a cyclical or circular way, and that is increasingly different, since it depends on the variables and the subjects of each investigation. The foregoing is deduced by the way in which events cannot always be predicted or anticipated, that is, their course is not always linear, but rather multifactorial, so that the analysis of an investigation, from observation itself, must try to cover most of these factors in order to obtain results that are as close as possible to reality.

Given the case of the nature of this study, with this method, it is intended to know the reality in which the subjects develop, create their expectations for discipline, culture, and preferences.

\section{Conclusions}

The development of this project will generate a database on the study material of schools today. The study will also allow us to observe the understanding and appropriation of techniques and their relationship in social and cultural areas, taking popular music as the axis. In this way, the project is related to the two educational levels of the Autonomous University of Sinaloa, and its impact in terms of the construction of identities, analysis and understanding and it also strengthens understanding and analysis, which benefits several top-tier schools in relation to the income capabilities of students. Likewise, what is the reception of the proposed topics and be part of the Department of Documentation and Research of Music in Sinaloa, as well as the review and analysis of current educational programs that are already in the upper middle system, such as those of the level superior in the areas of Humanities and Social Sciences. 


\section{References}

ALBERT G. M. J. (2006). La investigación Educativa, claves teóricas. Edit. Mc.GrawHill. España.

ARETZ I. (2004). América Latina en su música, UNESCO XXI siglo veintiuno editores, serie América Latina en su cultura, México.

ARNAU G. J. Anguera M.T. Gómez B. J. (1990). Metodología de la investigación en ciencias del comportamiento. Universidad de Murcia. Editorial Compobell S.A. Murcia.

BELLO M. E. (2003). Educación y globalización. Los discursos educativos en Iberoamérica. Editorial Anthropos. Barcelona.

BORBÓN R. (2016). La radio que nunca se apaga. Escenarios de la radiodifusión mexicana, Universidad Autónoma de Sinaloa, México.

CARPENTER S. y J. P. (2007). Etnohistoria de la tierra caliente, los grupos indígenas de Sinaloa al momento del contacto español, DIFOCUR, primera edición, Sinaloa, México.

CEPAL Naciones Unidas. Panorama social de América Latina. Determinantes, factores y circunstancias que favorecen la deserción escolar, 2001-2002, impreso para las Naciones Unidas en Santiago de Chile.

CLEMENTE B. J. A. (2002). "El contenido melódico en la enseñanza de la guitarra". Departamento de Teoría e Historia de la Educación, Facultad de Educación, Universidad de Murcia, España.

CORBETTA P. (2010). Metodología y técnicas de investigación social, Mc Graw Hill, España.

DE BONO E. (2002). El pensamiento lateral (manual de la creatividad), Editorial Paidós plural, México.

DE LA TORRE S. (1997). Creatividad y formación: Identidad, Diseño y Evaluación. Editorial trilla, México.

DÍAZ G. M. (2005). La educación musical en la escuela y el espacio europeo de educación superior, Revista Interuniversitaria de Formación de Profesorado, vol. 19, núm. 1, Universidad de Zaragoza España.
GARCÍA De M. A. (2013). Nuevos principios de lógica y epistemología (nuevos aspectos de la filosofía), UNAM, México, D.F.

GARCÍA R. J. (2009). Creatividad y docentes universitarios, el caso de la licenciatura en administración de empresas de la Universidad de Occidente, Sinaloa, México, Editorial Maritza López.

GARDNER H. A. (1995). Estructuras de la mente. TIM. Barcelona: Paidós Ibérica.

GIRÁLDEZ A. M, (2010). Investigación, innovación y buenas prácticas. edit. Grao, Barcelona España.

HERNANDEZ B. B. (2001). Técnicas estadísticas de investigación social. Editorial Díaz de Dantos, Madrid, España 2001.

HERNÁNDEZ S. R., Fernández C.C., Baptista L. M.P. (2006). Metodología de la investigación, Mc Graw-Hill 4ta. Edición, México.

HERNÁNDEZ S. R., Fernández C.C., Baptista L. M.P. (2014). Metodología de la investigación, Mc Graw-Hill 6ta. Edición, México.

IZCARA P. S. P. (2006). La praxis de la investigación cualitativa, guía para elaborar tesis, edit. Plaza y Valdez, México.

LAGO C. P. (2012). La musicoterapia en el tratamiento educativo de la diversidad, UNED (Universidad Nacional de Educación a Distancia, Madrid.

LAZCANO J. (2007). El Chicomoztoc de Culhuacán. Universidad Autónoma de Sinaloa, Instituto de Investigaciones económicas y sociales, editorial UAS, Segunda Edición, Sinaloa México.

LINES D. K. (2009). La educación musical para el nuevo milenio, el futuro de la teoría y la práctica de la enseñanza de la música. Edic. Morata, España.

LÓPEZ L. S. Y Corona T. L. (2010). Gestión y Políticas del Conocimiento y La Innovación. Experiencias Internacionales. Universidad Autónoma de Sinaloa, Red de Investigación y docencia e innovación Tecnológica, 1ra. Edición, Sinaloa, México. 
MANRESA, N. E., SUBIRÀ, M. M. A. P. I., \& TOVAS, Y. G. L. Facultad de CienciasSociales en Manresa (UVic-UCC). INNOVACIÓN DOCENTE E INVESTIGACIÓN EN EDUCACIÓN Y CIENCIAS SOCIALES.

MARÚM E. E. (2012). Calidad e innovación en la educación superior mexicana. Encuentros, desencuentros y nuevas interpretaciones. Centro para la calidad e innovación de la Educación Superior del Centro Universitario de Ciencias Económico-Administrativas de la Universidad de Guadalajara, Jalisco, México.

Martín, N. J. I., Minte-Münzenmayer, A. R., \& Llano, F. A. (2020). Música y aprendizaje histórico. Relaciones pedagógicas entre Euterpe y Clío. (pensamiento),(palabra)... Y obra, (23).

Martínez Lillo, R. I. (2020). Al-Ándalus: de paraíso recobrado a experiencia esencial.

MORALES S. (1981). La música mexicana, raíces compositores e intérpretes. editorial universo México.

NEBREDA G.P.L. (2015). La inteligencia musical, edición bubok publishing, S.L. España. Ortiz-Molina, M. A., \& Sadio-Ramos, F. J. (2020). Investigación, recuperación y estudio del patrimonio musical popular de una aldea del centro de Portugal. Revista Brasileira De Educação Do Campo, 5, 1-19.

QUINTANILLA S. (1997). La educación en México durante el periodo de Lázaro Cárdenas 1934-1940, diccionario de las ciencias de la educación, 5ta. Reimpresión, editorial Santillana S.A. de C.V. p. 475.

RODRÍGUEZ G. G. Gil, F. J. y García, J. E. (1999). Metodología de la Investigación Cualitativa. Edit. EA, España, p-174.

Salvado, M. A. (2020). ¿ Los españoles también pueden ser latinos? La identidad española en la música popular latina actual: el caso de $\mathrm{C}$. Tangana. Contrapulso-Revista latinoamericana de estudios en música popular, 2(1), 20-34.

SÁNCHEZ M. J. M. (2005). La dimensión humanística de la música, reflexiones y modelos didácticos. Ministerio de Educación y Ciencia, Secretaria General de Educación, España.
SANDIN E. M. (2003). Investigación Cualitativa en Educación. Fundamentos y Tradiciones Mc Graw Hill. Capítulo 2. Páginas 27 a 34, España

TAMAYO T. M. (2002). El proceso de la investigación científica. Editorial Limusa. 4ta. Edición México, D.F.

UNIDAD ACADÉMICA DE ARTES, (2015). Escuela de Música de la Universidad Autónoma de Sinaloa. México

VERA N. Torres M. y Martínez G. (2014). Evaluación de Competencias Básicas en TIC en Docentes de Educación Superior en México. 